\title{
Feeding ecology of a stream fish assemblage in an Atlantic Forest remnant (Serra do Japi, SP, Brazil)
}

\author{
Ana Paula Pozzo Rios Rolla ${ }^{1}$, Katharina Eichbaum Esteves ${ }^{2}$ \\ and Antônio Olinto Ávila-da-Silva ${ }^{3}$
}

This study aimed to characterize the trophic structure of the fish assemblage in streams of the Serra Japi, an ecotonal area between the Atlantic Forest and inland forests of São Paulo State, Southeastern Brazil. Fish were collected with electrofishing equipment in 15 sites covering different regions, substrate types and riparian vegetation, distributed throughout the Caguaçú River, Caxambú, Piraí and Guapeva River micro-basins, during the rainy (January/February) and dry season (June) of 2007. The 589 specimens analyzed from 22 species, were assigned to different trophic groups, discriminated through a matrix of similarity, based on the food index $\left(\mathrm{IA}_{\mathrm{i}}\right)$. The results show the formation of seven groups with a predominance of insectivorous and omnivorous species, followed by detritivores, piscivores, omnivore-carnivores and herbivores, which consumed mostly items of autochthonous origin, where algae and young insects were dominant. Canonical correspondence analysis (CCA), correlating the biomass of trophic groups to environmental variables, showed that omnivores, insectivores and omnivorecarnivores displayed a wide distribution, while detritivores, herbivores and piscivores were restricted to specific locations, related to different physical and chemical variables as total nitrogen, conductivity and temperature. Despite the increase in total biomass at the most urbanized sites, the results indicate that the streams maintain a diverse community, suggesting that most of them are in preserved conditions.

O presente trabalho teve por objetivo caracterizar a estrutura trófica da comunidade de peixes de riachos da Serra do Japi, uma área de transição entre a Mata Atlântica e o interior paulista, no sudeste brasileiro. Os peixes foram coletados com equipamento de pesca elétrica em 15 pontos localizados em regiões com diferentes tipos de substrato e vegetação ripária, distribuídos pelas microbacias do Ribeirão Caguaçú, Caxambú, Piraí e Rio Guapeva, durante as estações chuvosa (janeiro/fevereiro) e seca (junho) de 2007. Os 589 indivíduos analisados, pertencentes a 22 espécies, foram classificados em diferentes grupos tróficos, discriminados através de uma matriz de similaridade baseada no Índice Alimentar (IA $)$. Os resultados mostraram a formação de sete grupos com predomínio de espécies insetívoras e onívoras, seguidas pelas detritívoras, piscívoras, onívoro-carnívoras e herbívoras, que consumiram principalmente itens de origem autóctone com predomínio de algas e formas imaturas de insetos aquáticos. A Análise de Correspondência Canônica, ao correlacionar a biomassa dos grupos tróficos às variáveis ambientais, mostrou que as espécies onívoras, insetívoras e onívoro-carnívoras apresentaram ampla distribuição, enquanto que as detritívoras, herbívoras e piscívoras estiveram restritas a determinados locais, relacionados a diferentes variáveis físicas e químicas tais como nitrogênio total, condutividade e temperatura. Embora o aumento da biomassa de alguns grupos tróficos tenha sido verificado nos locais com maior influência antrópica, os resultados indicaram que os diferentes riachos mantêm uma fauna diversificada, sugerindo que estes se encontram em condições relativamente preservadas.

Key words: Tropical streams, Freshwater fish, Trophic ecology, Distribution.

\footnotetext{
${ }^{1}$ Pós-graduação em Aqüicultura e Pesca, Instituto de Pesca, Secretaria da Agricultura e Abastecimento do Estado de São Paulo, Av. Francisco Matarazzo, 455, 05001-900 São Paulo, SP, Brazil. anapaulaprr@yahoo.com.br

${ }^{2}$ Centro de Pesquisas e Desenvolvimento em Recursos Hídricos, Instituto de Pesca, APTA, Secretaria da Agricultura e Abastecimento do Estado de São Paulo.

${ }^{3}$ Centro do Pescado Marinho, Instituto de Pesca, APTA, Secretaria da Agricultura e Abastecimento do Estado de São Paulo.
} 


\section{Introduction}

The Atlantic Forest is one of the richest and most diverse ecosystems in the world, where it is considered one of the 25 hotspots of global biodiversity (Tabarelli et al., 2005). It is, however, one of the most threatened ecosystems (Myers et al., 2000), especially in the state of São Paulo, Southeastern Brazil, where forest cover has been reduced to about $10 \%$ (Castro \& Menezes, 1998). One of the most prominent threats in this ecosystem is related to the degradation of natural rivers and streams, which has occurred mainly due the loss of riparian vegetation, organic chemical pollution and the introduction of exotic species, causing the destruction of the habitat and reducing the food supply (Menezes et al., 1990). Additionally, little information in tropical environmental areas exists, with inventories for one or more groups of organisms restricted to approximately $5 \%$ of the tropical protected areas (Hawksworth, 1995).

Streams in the Atlantic rainforest harbor a rich fish fauna, with a high degree of endemism, and intimate association with the riparian vegetation, considered important for food, shelter and reproduction (Menezes et al., 1990; Menezes, 1994). Thus, several species represent an important link between the terrestrial and aquatic ecosystems (Gelwick \& Matthews, 1996), as some of the food consumed originates in the riparian forest (Sabino \& Castro, 1990).

Studies on fish communities in Atlantic Forest streams have been conducted in recent decades (Sabino \& Castro, 1990; Buck, 1994; Uieda, 1995; Esteves, 1996; Uieda \& Barreto, 1999; Vilella et al., 2002), focusing on the composition, distribution and feeding habits of species. Although studies regarding the trophic structure of food chains in streams are common (Luiz et al., 1998; Esteves \& Lobon-Cerviá, 2001; Motta \& Uieda, 2005; Uieda \& Motta, 2007; Esteves et al., 2008), they are still scarce in southeastern Brazil as compared to information related to rivers and reservoirs (Esteves \& Aranha, 1999).

Considering that large scale alterations in forest structure may have serious impacts on stream biodiversity, affecting shading, discharge, siltation and availability of food types (Angermeier \& Karr, 1983), an understanding of the trophic organization and food web structure can reveal fundamental properties of the stream ecosystem and help evaluate the influence of physical disturbance on the community and develop conservation strategies (Barreto \& Aranha, 2006).

The Serra do Japi is part of some state environmental protection areas (APAs) for sustainable use, characterized by a high diversity of life forms, and was put under governmental trust in 1983. It represents one of the last areas of continuous forest of São Paulo State (Morellato, 1992), being considered an ecotonal region, i.e., in transition between two forest formations - the Atlantic Forest of Serra do Mar and the inland forests of São Paulo (Instituto Serra do Japi, 1998). Because of its size and significant degree of conservation, it is one of the best examples of semideciduous forests of São Paulo, containing all the physiognomic components (Joly, 1992).

Little is known about the fish communities of the Serra do Japi streams, in spite of the growing impacts on these environments, resulting from increased removal of riparian vegetation, urban sprawl, and small dam construction. Focusing on streams under different conditions, this study aimed to examine the trophic ecology of the fish fauna, determining (1) the food spectrum of the different species, (2) the diversity of the trophic groups, and (3) the distribution of the trophic groups in relation to different environmental conditions.

\section{Materials and Methods}

Study area. The Serra do Japi is located to the west of the Atlantic Plateau, between the cities of Jundiaí, Cabreúva, Pirapora do Bom Jesus and Cajamar, in the state of São Paulo, in southeast Brazil (Fig. 1). It has an area of approximately 354 $\mathrm{km}^{2}$, characterized by a quartzitic soil (Ab 'Saber, 1992), relatively flattened hilltops and very steep slopes, with altitudes ranging from 700 to 1219 meters (Instituto Serra do Japi, 1998). Vegetation is composed by semideciduous altitudinal forests, semideciduous mesophyllic forests, gallery forests and rocky substrates (Joly, 1992). The average annual temperature varies between $15.7^{\circ} \mathrm{C}$ and $19.2^{\circ} \mathrm{C}$ with an annual rainfall of about $1400 \mathrm{~mm}$ (Instituto Serra do Japi, 1998).

Preservation of the vegetated areas has occurred partly due to the establishment of the mountain ridges under governmental trust (Serra do Japi, Guaxinduva and Jaguacoara), located in the environmental protection areas (APAs) of Jundiaí, Cabreúva and Cajamar. However, since the early XVIII century the Serra do Japi has suffered several human interferences such as timber exploitation, agricultural and urban uses, real estate speculation and deforestation. Part of the area is presently occupied by Pinus spp. and Eucalyptus spp. reforestation, pastures and small agricultural properties (Instituto Serra do Japi, 1998).

The streams in the area are predominantly clear water, originating in mountain escarpments and comprising waterfalls, rapids and slow flowing stretches. The main microbasins considered for this study are part of the Sorocaba/ Middle Tietê and Piracicaba-Capivari-Jundiaí sub-basins, both belonging to the Tietê River Basin, which is part of the Paraná River basin. Selection of sampling sites was based on the diversity of environmental conditions, represented both by preserved and deforested areas, as well as the existence of stream stretches with different types of substrate.

Fifteen sites distributed over different microbasins were sampled. In the Jundiaí APA, stretches of the Caguaçú River micro-basin, formed by São Jerônimo Stream (sampling site P1), its tributaries (P2, P9), Caguaçú River (P8 and P14), and the stream called here "Paiol Velho "(P7) - a small tributary of Cachoeira River - were sampled. Within this same APA, in the Guapeva River micro-basin, sites 4, 5 and 6 located in Pedreiras 


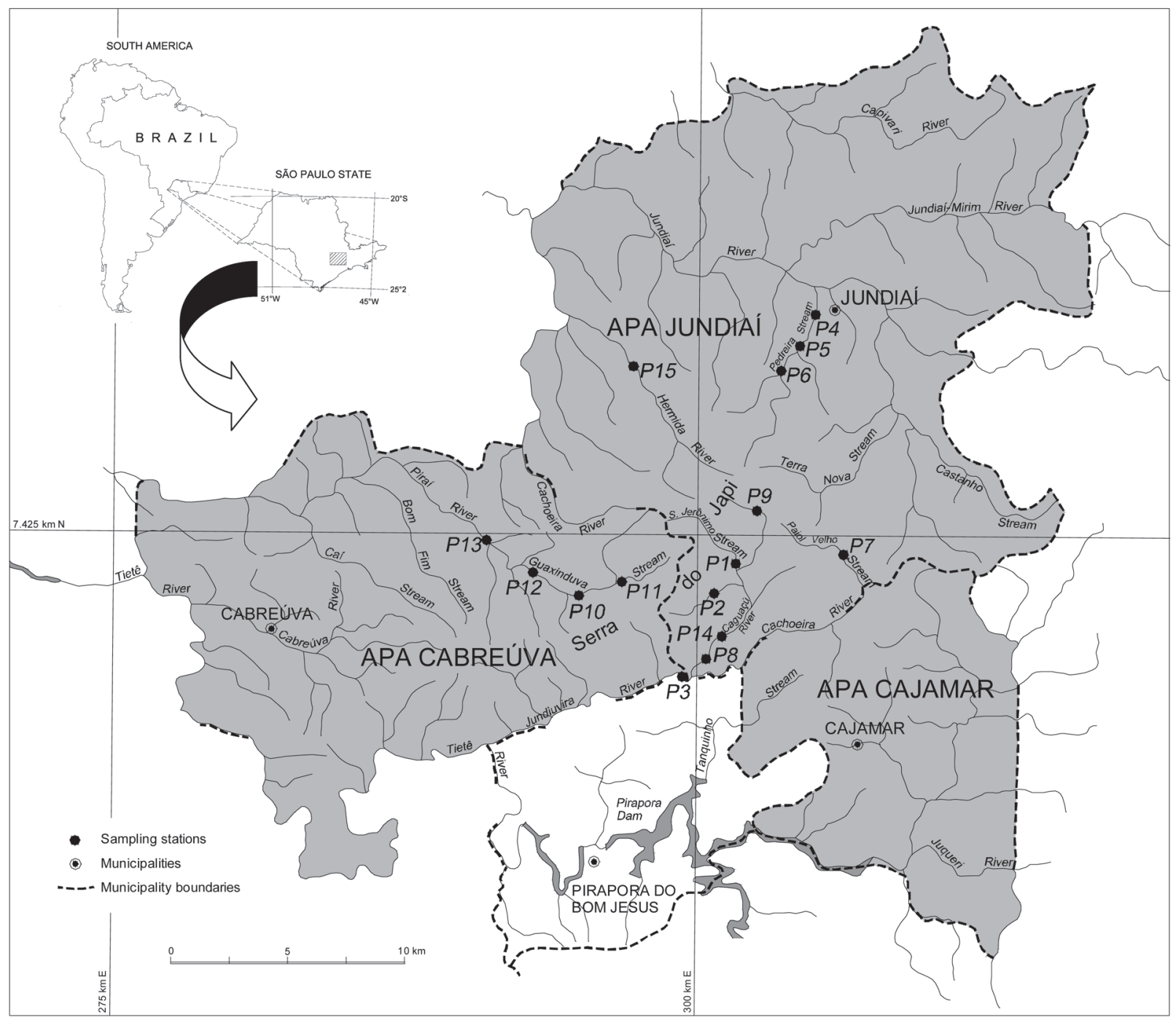

Fig. 1. Location of the Serra Japi in the APAs of Jundiaí, Cabreúva, Cajamar and in the municipality of Pirapora do Bom Jesus (SP), showing sampling sites in the different streams. Adapted from "Atlas das Unidades de Conservação Ambiental do Estado de São Paulo- Parte II-Interior, SMA, 1998”.

Stream, and Hermida River in the Caxambu River micro-basin (P15) were selected. In the Cabreúva APA, sites P10, P11, P12, and P13 were located in Guaxinduva Stream (Piraí River micro-basin) and site P3 in Jundiuvira River, which belongs to the Caguaçú River micro-basin (Fig. 1).

Most of the stations were located in relatively preserved areas, with a predominance of native forest $(\mathrm{P} 1, \mathrm{P} 2, \mathrm{P} 8, \mathrm{P} 10$, $\mathrm{P} 11, \mathrm{P} 12$, and P14). Sites P9 and P15 were located in pasture areas and $\mathrm{P} 3, \mathrm{P} 4, \mathrm{P} 5, \mathrm{P} 6, \mathrm{P} 7$ and $\mathrm{P} 13$ in areas subject to anthropogenic influences, where riparian vegetation is disturbed and there is discharge of domestic sewage.

Data collection. Fish samples were obtained during the rainy (January/February) and dry season (June) of 2007 using stationary electrofishing equipment (HONDA EX 1000 generator, $120 \mathrm{~V}, 60 \mathrm{~Hz},<2.5 \mathrm{Amp}$., AC). This configuration was similar to that used by Mazzoni et al. (2000), who found that sampling efficiency was not affected in an Atlantic Forest stream which presented varying conductivities. At each site three successive catches were conducted over a $50-\mathrm{m}$ stretch, following the 3-catch removal method (Zippin, 1958), resulting in a constant fishing effort at each locality. Borders were blocked with nets of 1.3-mm mesh size to prevent fish from escaping. Samples were fixed in $10 \%$ formalin solution and preserved in $70 \%$ alcohol, and specimens were identified according to Britski (1972) and Britski et al. (1986), which was later confirmed by a specialist of the Museum of Zoology of the University of São Paulo, where a voucher was deposited.

The following environmental characteristics were recorded for each sampling site: altitude (m), depth (m), width $(\mathrm{m})$, water speed $\left(\mathrm{m} \cdot \mathrm{s}^{-1}\right)$ - according to the float method of Marques \& Argento (1988); flow $\left(\mathrm{m}^{3} \cdot \mathrm{s}^{-1}\right)$, using the formulae $\mathrm{Q}=\mathrm{W} \times \mathrm{A} \times \mathrm{S}$, where $\mathrm{Q}=$ flow, $\mathrm{W}=$ width, $\mathrm{A}=$ area and $\mathrm{S}=$ water speed; riparian vegetation cover (\%), recorded as the 
percentage shading of the stream channel; proportion of rapids and pools $(\%)$ - relative proportion of each type in a $50 \mathrm{~m}$ long stretch; predominant substrate, visually classified as the relative proportion of sand $(\cong 3 \mathrm{~mm})$, fine gravel $(\cong 3$ to $49 \mathrm{~mm}$ ), coarse gravel (50 to $149 \mathrm{~mm})$, small boulders (150 to $300 \mathrm{~mm}$ ) or large boulders $(>300 \mathrm{~mm})$, and presence of impoundments in the surroundings. Physicochemical parameters for each site, such as water temperature $\left({ }^{\circ} \mathrm{C}\right)$, dissolved oxygen (OD) (mg. $\left.\mathrm{L}^{-1}\right), \mathrm{pH}$, conductivity $\left(\mu \mathrm{S} . \mathrm{cm}^{-1}\right)$ and total dissolved solids (mg. $\mathrm{L}^{-1}$ ) were measured in the field with a multi-parameter water quality monitoring system (HORIBA U-22). Other analyses included ammonia (mg.L $\left.\mathrm{L}^{-1}\right)$, dissolved phosphorus $\left(\mu \mathrm{g} . \mathrm{L}^{-1}\right)$, total suspended solids $\left(\mathrm{mg} . \mathrm{L}^{-1}\right)$,

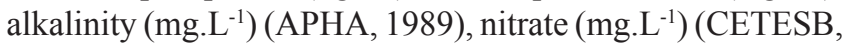
1978), nitrite $\left(\mu \mathrm{g} . \mathrm{L}^{-1}\right)(\mathrm{FEEMA}, 1981)$, total nitrogen (mg. $\left.\mathrm{L}^{-1}\right)$ and total phosphorus (ìg. $\mathrm{L}^{-1}$ ) (Strickland \& Parsons, 1968).

Diet analysis. Sub-samples of 20 individuals for the most abundant species for each season were taken, while for the remaining ones, the total number was analyzed. Gut contents were analyzed according to the method of frequency of occurrence and points method (Hynes, 1950), and counted in a counting chamber under a light microscope and stereomicroscope $(25 \mathrm{X})$. For this latter method, the stomach was opened and given a score that varied from 0 to 20 , related to the total food volume. Items were then grouped into different categories, and a number of points assigned to each one, according to the volume occupied in relation to the total volume. The volumetric proportion of each category was calculated, considering $100 \%$ as the sum of points assigned to each one.

Frequency of occurrence of each item was correlated with volumetric data using the feeding index $\left(\mathrm{IA}_{\mathrm{i}}\right)$ proposed by

$$
I A_{i}=\frac{F_{i} \times V_{i}}{\sum_{x=1}^{n}\left(F_{i} \times V_{i}\right)} \times 100
$$

Kawakami \& Vazzoler (1980) and adapted by Hahn et al. (1997b), and is described by the equation:

where $\mathrm{i}=1,2, \ldots . ., \mathrm{n}$ food items; $\mathrm{F}_{\mathrm{i}}=$ frequency of occurrence $(\%)$ of a given food item; $\mathrm{V}_{\mathrm{i}}=$ volume $(\%)$ of a given food item.

Diet similarity of fish species, based on the IA ${ }_{i}$ was analyzed through a triangular similarity matrix between pairs of species, after square-root transformation. Based on this matrix, a dendrogram using Bray-Curtis distance and Ward's clustering method and ordinations by non-metric multidimensional scaling (NMDS) were obtained. NMDS is a nonparametric procedure that uses ranks of the similarities between samples to construct a map in which the positions of the samples reflect as closely as possible the dissimilarities among them. The stress value is a measure of the accuracy of this representation, with a value below 0.1 indicating a reliable representation (Clarke \& Warwick, 1994).
After assigning fish assemblage to different trophic groups, the biomass for each one, considering both seasons was totaled, and a canonical correspondence analysis (CCA) was used to determine the relationships between the biomass of each trophic group and environmental variables including habitat characteristics and physicochemical water parameters. The environmental matrix was based on the average values between the dry and rainy season, and was standardized, while biological data were transformed into log $(\mathrm{x}+1)$. Some species may be classified into different trophic groups according to the resolution level adopted, and therefore insectivores and benthic insectivores were grouped for the biomass calculations, since we opted to place fish in feeding guilds that resembled them most, as has been adopted in other studies (Jeppesen et al., 2000).

For this analysis, a stepwise backward selection procedure was performed to produce a parsimonious model. Starting with the full model including all explanatory variables, Akaike's Information Criterion (AIC) was used to assess the change in model performance resulting from excluding individual explanatory variables. At each step in this procedure, the change in AIC compared to the current model was evaluated and the model that resulted in the lowest AIC was selected. A correlation between the weighted average scores and linear combination scores was used and ANOVA was applied to test the significance of the model. All statistical analyses were carried out using the statistical computing software R (R Development Core Team, 2007) and the package vegan (Oksanen et al., 2007).

\section{Results}

Environmental variables. General environmental characteristics of the different sampling zones are summarized in Table 1. The results indicated few differences among sampling sites, with most of them being characterized by the presence of rapids, high concentration of dissolved oxygen, small depth and width, and a predominance of sand and coarse gravel in the substrate. Percentage vegetation cover also varied, with open pasture areas (P9 and P15) and closed canopy sites (P1, P2, P8, P10, P11 and P14). Higher values of conductivity occurred at sites under anthropogenic influences (P4, P5, P6 and P7) and higher order streams (P3, P8), while discharge showed the highest values at P3 and P12.

Trophic group assignment. From a total of 2474 specimens belonging to 10 families and 29 species obtained during the dry and rainy seasons, 589 stomachs from 22 species were considered for the analysis. Major food types, grouped into 12 broad categories included algae, adult insects, young insects (larvae, nymphs and pupae), insect fragments (with predominance of exoskeleton), vegetal matter (seeds and leaf parts), organic matter (amorphous material of animal or plant origin), detritus, crustaceans, fish, nematodes, annelids and other (low occurrence items such as cladocera, copepods, ostracods, bivalves, fish scales, arachnids, and mites). The 
importance of these categories in fish diet is shown through the results of the $\mathrm{IA}_{\mathrm{i}}$ (Table 2).

Analysis of the NMDS resulted in seven trophic groups, with a stress value of 0.05 , indicating good ordination and confidence in the representation of the results (Fig. 2). These groups were characterized as follows:

Group 1: Benthic insectivores - This group was represented by Trichomycterus sp. (Trsp), Characidium gomesi (Chgo) and Characidium oiticicai (Choi), which consumed predominantly young insects of benthic origin ( $\mathrm{IA}_{\mathrm{i}}: 40-65 \%$ ) (Table 2 ), with high occurrence of chironomidae, simuliidae, trichoptera and ephemeroptera (Table 3). Insect fragments also contributed with significant proportions in the diet of these species.

Group II: Insectivores - These included species such as Astyanax paranae (Aspa), Astyanax altiparanae (Asal), Astyanax bockmanni (Asbo), Gymnotus carapo (Gyca), Bryconamericus stramineus (Brstr), Cetopsorhamdia iheringi (Ceih), Imparfinis mirini (Immi) and Trichomycterus brasiliensis (Trbr), which represented $36.3 \%$ of all species. Insect fragments were the preferential food item (IA : $39-$ $62 \%$ ), followed by young insects ( $\mathrm{IA}_{\mathrm{i}}: 12-27 \%$ ) composed of chironomidae, trichoptera, simuliidae and unidentified diptera larvae (Table 3).

Group III: Detritivores - This group was formed by three species (13.6\% of species analyzed), composed of Pareiorhina sp. (Pasp), Hisonotus depressicauda (Hide) and
Hypostomus ancistroides (Hyan). These species exploited the bottom, ingesting large amounts of detritus (IA $\mathrm{A}_{\mathrm{i}}$ : 65-78\%), followed by organic matter and algae, which were also important, as they were probably deposited on the sediment ( $\mathrm{IA}_{\mathrm{i}}$ : $5-16 \%)$.

Group IV: Herbivores - This group contained only Tilapia rendalli (Tire) ( $4.5 \%$ of species analyzed), which fed preferentially on plant fragments ( $\mathrm{IA}_{\mathrm{i}}: 72 \%$ ), followed by algae (mainly diatoms) and organic matter. Insects, detritus and fish showed low occurrence.

Group V: Omnivores - These fish included species such as Corydoras aeneus (Coae), Geophagus brasiliensis (Gebr), Neoplecostomus paranensis (Nepa), Phalloceros sp. (Phsp) and Poecilia reticulata (Pore) (22.8\% of species analyzed). Food habits included a variety of items such as algae, plant pieces, insect fragments, young insects, detritus, nematodes, oligochaeta and organic matter (Table 3). Phalloceros sp. and $P$. reticulata displayed the highest values of detritus $\left(\mathrm{IA}_{\mathrm{i}}=40 \%\right)$ and organic matter $\left(\mathrm{IA}_{\mathrm{i}}=36.3 \%\right)$.

Group VI: Piscivores - The group was composed of Hoplias malabaricus (Homa) (4.5\% of species analyzed), where this species had a diet consisting exclusively of fish $\left(\mathrm{IA}_{\mathrm{i}}=99 \%\right)$. Other items such as insect fragments, plant matter and organic matter were rare in the diet.

Group VII: Omnivores with a tendency to carnivory - Formed by $R$. quelen, which represented $4.5 \%$ of species that had

Table 1. Main characteristic and physicochemical water parameters (average values - rainy and dry season) in 15 sites of the Serra do Japi streams (APA Cabreúva and Jundiaí). DO= Dissolved oxygen; TDS= Total Dissolved Solids; $\mathrm{s}=\mathrm{sand}$; $\mathrm{fg}=$ fine gravel; $\mathrm{cg}=$ coarse gravel; $\mathrm{sb}=$ small boulder; $\mathrm{lb}=$ large boulder $; \mathrm{nf}=$ native forest; $\mathrm{s} f=$ secondary forest; Zyn= Zyngiberaceae $(+)$ presence; (-) absence.

\begin{tabular}{|c|c|c|c|c|c|c|c|c|c|c|c|c|c|c|c|}
\hline Parameters & P1 & $\mathrm{P} 2$ & P3 & P4 & P5 & P6 & P7 & P8 & P9 & $\mathrm{P} 10$ & P11 & P12 & P13 & P14 & P15 \\
\hline & $\begin{array}{c}\text { São } \\
\text { Jerônimo } \\
\text { stream }\end{array}$ & $\begin{array}{l}\text { Tributary } \\
\text { of São } \\
\text { Jerônimo }\end{array}$ & $\begin{array}{c}\text { Jundiú- } \\
\text { vira } \\
\text { River }\end{array}$ & $\begin{array}{c}\text { Pedreira } \\
\text { stream }\end{array}$ & $\begin{array}{c}\text { Pedreira } \\
\text { stream }\end{array}$ & $\begin{array}{l}\text { Pedreira } \\
\text { stream }\end{array}$ & $\begin{array}{c}\text { Paiol } \\
\text { Velho } \\
\text { stream }\end{array}$ & $\begin{array}{l}\text { Caguaçú } \\
\text { River }\end{array}$ & $\begin{array}{l}\text { Tributary } \\
\text { of São } \\
\text { Jerônimo }\end{array}$ & $\begin{array}{l}\text { Guaxin- } \\
\text { duva } \\
\text { stream }\end{array}$ & $\begin{array}{c}\text { Guaxin- } \\
\text { duva } \\
\text { stream }\end{array}$ & $\begin{array}{l}\text { Guaxin- } \\
\text { duva } \\
\text { stream }\end{array}$ & $\begin{array}{c}\text { Guaxin- } \\
\text { duva } \\
\text { stream }\end{array}$ & $\begin{array}{l}\text { Caguaçú } \\
\text { River }\end{array}$ & $\begin{array}{c}\text { Hermida } \\
\text { River }\end{array}$ \\
\hline Coordinates & $\begin{array}{l}23^{\circ} 17^{\prime} 01.2^{\prime \prime} \\
46^{\circ} 56^{\prime} 21.4^{\prime \prime}\end{array}$ & $\begin{array}{l}23^{\circ} 17^{\prime} 23.7^{\prime \prime} \\
46^{\circ} 56^{\prime} 52.2^{\prime \prime}\end{array}$ & $\begin{array}{l}23^{\circ} 19^{\prime} 32.2^{\prime \prime} \\
46^{\circ} 57^{\prime} 43.5^{\prime \prime}\end{array}$ & $\begin{array}{l}23^{\circ} 14^{\prime} 44.1^{\prime \prime} \\
46^{\circ} 53^{\prime} 15.4^{\prime \prime}\end{array}$ & $\begin{array}{l}23^{\circ} 15^{\prime} 08.1^{\prime \prime} \\
46^{\circ} 53^{\prime} 51.5^{\prime \prime}\end{array}$ & " $23^{\circ} 15^{\prime} 11.3^{\prime \prime}$ & $\begin{array}{l}23^{\circ} 16^{\prime} 51.2^{\prime} \\
46^{\circ} 53^{\prime} 42.4^{\prime}\end{array}$ & $\begin{array}{l}23^{\circ} 18^{\prime} 50.4^{\prime \prime} \\
46^{\circ} 56^{\prime} 52.7^{\prime \prime}\end{array}$ & $\begin{array}{l}23^{\circ} 15^{\prime} 38.9^{\prime \prime} \\
46^{\circ} 55^{\prime} 47.4^{\prime \prime}\end{array}$ & $\begin{array}{l}23^{\circ} 17^{\prime} 36.5^{\prime \prime} \\
47^{\circ} 00^{\prime} 13.4^{\prime \prime}\end{array}$ & $\begin{array}{l}23^{\circ} 17^{\prime} 15.3^{\prime \prime} \\
46^{\circ} 59^{\prime} 09.7^{\prime \prime}\end{array}$ & $\begin{array}{l}23^{\circ} 17^{\prime} 01.8^{\prime \prime} \\
47^{\circ} 01 ' 29.3 "\end{array}$ & $\begin{array}{l}23^{\circ} 16^{\prime} 18.1 \\
47^{\circ} 02^{\prime} 35.2\end{array}$ & $\begin{array}{l}23^{\circ} 18^{\prime} 34.8^{\prime \prime} \\
46^{\circ} 56^{\prime} 38.8^{\prime \prime}\end{array}$ & $\begin{array}{l}23^{\circ} 12^{\prime} 15.9^{\prime \prime} \\
46^{\circ} 58^{\prime} 52.8^{\prime \prime}\end{array}$ \\
\hline Dominant substrate & $\mathrm{s} / \mathrm{sb} / \mathrm{lb}$ & $\mathrm{s} / \mathrm{fg} / \mathrm{cg}$ & $\mathrm{s} / \mathrm{cg}$ & $\mathrm{s} / \mathrm{cg}$ & $\mathrm{s} / \mathrm{cg}$ & $\mathrm{lb} / \mathrm{sb}$ & s/silt & $\mathrm{s} / \mathrm{cg}$ & $\mathrm{s} / \mathrm{cg}$ & $\mathrm{s} / \mathrm{cg}$ & $\mathrm{cg} / \mathrm{sb}$ & $\mathrm{s} / \mathrm{sb}$ & $\mathrm{s} / \mathrm{cg}$ & $\mathrm{s} / \mathrm{fg}$ & $\mathrm{s} / \mathrm{fg}$ \\
\hline Altitude (m) & 890 & 830 & 807 & 858 & 802 & 805 & 804 & 694 & 927 & 930 & 924 & 854 & 861 & 798 & 740 \\
\hline Order & $4^{a}$ & $4^{a}$ & $5^{a}$ & $4^{a}$ & $4^{a}$ & $4^{a}$ & $3^{\mathrm{a}}$ & $5^{\mathrm{a}}$ & $4^{a}$ & $4^{a}$ & $4^{\mathrm{a}}$ & $5^{a}$ & $5^{a}$ & $5^{\mathrm{a}}$ & $4^{a}$ \\
\hline $\begin{array}{l}\text { Riparian } \\
\text { Vegetation }\end{array}$ & $\mathrm{nf}$ & $\begin{array}{l}\text { nf } \\
\text { Zyn }\end{array}$ & $\begin{array}{c}\text { sf } \\
\text { Zyn }\end{array}$ & $\begin{array}{c}\text { sf, Zyn } \\
\text { bamboo }\end{array}$ & $\begin{array}{c}\text { grass, sf } \\
\text { Zyn }\end{array}$ & $\begin{array}{c}\text { Eucalyptus } \\
\text { Zyn }\end{array}$ & $\begin{array}{c}\text { sf } \\
\text { bamboo }\end{array}$ & $\mathrm{nf}$ & pasture & $\mathrm{nf}$ & $\mathrm{nf}$ & Zyn & grass & $\begin{array}{c}\mathrm{nf} \\
\mathrm{Zyn}\end{array}$ & pasture \\
\hline $\mathrm{PH}$ & 6.84 & 6.65 & 6.58 & 6.79 & 6.67 & 6.53 & 6.53 & 6.58 & 6.6 & 6.85 & 6.72 & 6.81 & 6.73 & 6.93 & 6.63 \\
\hline DO $\left(\mathrm{mg} . \mathrm{L}^{-1}\right)$ & 13.31 & 13.77 & 11.72 & 13.16 & 11.08 & 11.08 & 11.09 & 12.01 & 12.11 & 12.02 & 12.09 & 12.66 & 12.66 & 12.17 & 12.82 \\
\hline Temp. $\left({ }^{\circ} \mathrm{C}\right)$ & 17.07 & 17.86 & 17.58 & 19.70 & 19.6 & 19.95 & 19.05 & 17.68 & 17.82 & 17.14 & 17.38 & 17.88 & 19.38 & 18.14 & 19.55 \\
\hline TDS (mg.L $\left.{ }^{-1}\right)$ & 0.02 & 0.02 & 0.04 & 0.04 & 0.04 & 0.03 & 0.05 & 0.03 & 0.02 & 0.02 & 0.02 & 0.01 & 0.02 & 0.02 & 0.02 \\
\hline $\begin{array}{l}\text { Conductivity } \\
\left(\mu \mathrm{S} . \mathrm{cm}^{-1}\right)\end{array}$ & 36.00 & 29.00 & 61.50 & 56.5 & 56.5 & 43.00 & 79.5 & 42.5 & 35.5 & 28.00 & 29.50 & 19.00 & 26.00 & 27.50 & 22.00 \\
\hline Width (m) & 3.23 & 1.76 & 7.93 & 3.40 & 2.89 & 2.89 & 3.06 & 4.95 & 1.35 & 3.12 & 2.79 & 5.50 & 3.73 & 4.39 & 2.14 \\
\hline Depth (m) & 0.29 & 0.17 & 0.50 & 0.31 & 0.39 & 0.26 & 0.25 & 0.37 & 0.33 & 0.42 & 0.16 & 0.31 & 0.69 & 0.49 & 0.54 \\
\hline Canopy cover (\%) & 85.00 & 90.00 & 50.00 & 65.00 & 40.00 & 75.00 & 75.00 & 75.00 & 0.00 & 85.00 & 98.00 & 25.00 & 25.00 & 80.00 & 0.00 \\
\hline Water speed $\left(\mathrm{m} \cdot \mathrm{s}^{-1}\right)$ & 0.41 & 0.47 & 0.56 & 0.48 & 0.31 & 0.41 & 0.29 & 0.58 & 0.59 & 0.80 & 0.48 & 1.04 & 0.34 & 0.49 & 0.40 \\
\hline Discharge $\left(\mathrm{m}^{3} \mathrm{~s}^{-1}\right)$ & 1.29 & 0.19 & 13.20 & 1.20 & 0.99 & 0.39 & 0.51 & 4.80 & 0.17 & 2.86 & 0.57 & 6.41 & 2.89 & 3.98 & 1.40 \\
\hline Runs (\%) & 30 & - & - & - & - & - & - & - & - & - & - & 5 & - & - & - \\
\hline Riffles (\%) & 60 & 90 & 60 & 100 & 90 & 80 & 65 & 70 & 85 & 85 & 80 & 95 & 20 & 75 & 90 \\
\hline Shallow pools $(\%)$ & 10 & 10 & 40 & & 10 & 20 & 45 & 30 & 15 & 15 & 20 & - & 80 & 25 & 10 \\
\hline Trunks/roots (\%) & 2.5 & 9.0 & 8.0 & 5.0 & 5.0 & 2.5 & 2.0 & 15.0 & 0.0 & 8.0 & 4.0 & 4.0 & 3.0 & 10.0 & 3.0 \\
\hline Impoundment & - & - & - & + & + & + & - & - & + & + & + & - & - & - & + \\
\hline
\end{tabular}


their diet analyzed. This species consumed similar proportions of insect fragments $(\mathrm{IAi}=23.5 \%)$, crustaceans ( $\mathrm{IAi}=$ $23.3 \%)$ and organic matter $(\mathrm{IAi}=24.5 \%)$. Other items such as fish, immature insects and annelids were also important in the diet of this species.

Insect fragments, detritus, plant pieces, organic matter, aquatic insects and algae (Bacyllariophyceae and Chlorophyceae) were the food items consumed most often by the fish assemblage (Table 3). Terrestrial resources were not commonly represented in the diet of most of the species, while plant pieces and organic matter occurred more frequently.

Relationships between trophic groups and environmental variables. Biomass of the different trophic groups indicated a predominance of omnivores (37\%) and insectivores (28\%), followed by piscivores $(16 \%)$, omnivores with a tendency to carnivory (8\%), detritivores (7\%) and herbivores (4\%). Distribution of total biomass among the sites indicated that P4, P5, P6 and P7 had the highest values of total biomass (Fig. 3).

Stepwise procedure selected the variables Total Nitrogen $(\mathrm{AIC}=28.320)$; water velocity $(\mathrm{AIC}=24.726)$; temperature $(\mathrm{AIC}=23.482)$ and conductivity $(\mathrm{AIC}=22.073)$. The canonical correspondence analysis (CCA) between the trophic groups and selected environmental variables ( $p>0.005$ ), explained $68 \%$ of the total variance ( $62 \%$ on the first two axes), indicating that total nitrogen, temperature and conductivity in axis 1 and total nitrogen in axis two, were the most important factors in the distribution of the trophic groups (Table 4). Figure 4 shows that omnivores, insectivores and omnivores with a tendency to carnivory were widely distributed in the study area, while detritivores, piscivores and herbivores were associated with specific variables. Detritivore biomass was nega- tively correlated with temperature and conductivity, and positively with water velocity. Herbivores showed a strong correlation to total nitrogen and low water velocity at an open area pasture site (P9), while piscivores were associated with higher temperature and conductivity values (P3, P4, P6 and P7).

\section{Discussion}

The biotic composition of streams is strongly influenced by physical habitat. Important aspects of habitat structure include channel morphology, water depth, water velocity and flow, cover and substratum composition (Gorman \& Karr, 1978; Schlosser, 1990). Riparian buffer zones also have an important role in linking a stream to its watershed, once they may control within stream communities by influencing solar radiation, water temperature, nutrient budgets, stabilization of stream banks, also providing a source of organic energy (Schiemer \& Zalewski, 1992).

Habitats of Serra do Japi streams presented a high variety of environmental conditions with clear water where dense native riparian forest is found, as well as degraded sites. Human settlement has probably impacted these areas, altering local conditions through impoundment construction, sewage discharge and removal of riparian forest. Several studies show that fish communities respond to the effects of human activities, which may affect diversity, richness, abundance, growth and trophic organization (Karr, 1981; Rabeni \& Smale, 1995; Paul \& Mayer, 2001).

The streams were numerically dominated by fishes with relatively generalized diets (insectivores and omnivores), followed by more specialized fish (detritivores, herbivores and piscivores). The predominance of insectivorous species is

Table 2. Feeding Index $\left(\mathrm{IA}_{\mathrm{i}}\right)$, which combines frequency of occurrence (\%) and volume (\%) of food items consumed by the different fish species of Serra do Japi streams (dry and rainy season). Preferential food items are marked in bold.

\begin{tabular}{|c|c|c|c|c|c|c|c|c|c|c|c|c|c|c|}
\hline Species & Code & Voucher & Algae & $\begin{array}{c}\text { Adult } \\
\text { insects }\end{array}$ & $\begin{array}{l}\text { Young } \\
\text { insects }\end{array}$ & $\begin{array}{l}\text { Insect } \\
\text { frag- } \\
\text { ments }\end{array}$ & Vegetal & $\begin{array}{l}\text { Organic } \\
\text { matter }\end{array}$ & Detritus & $\begin{array}{c}\text { Crusta- } \\
\text { cea }\end{array}$ & Fish & $\begin{array}{c}\text { Nemato- } \\
\mathrm{da}\end{array}$ & $\begin{array}{l}\text { Anneli- } \\
\text { da }\end{array}$ & Other \\
\hline Astyanax bockmanni & Asbo & 98806 & 0.55 & - & 10.24 & 41.97 & 6.67 & 38.90 & 1.34 & - & 0.17 & 0.14 & - & 0.02 \\
\hline Bryconamericus stramineus & Brst & 98809 & 2.97 & - & 26.39 & 50.08 & 7.08 & 12.51 & 0.97 & - & - & - & - & - \\
\hline Cetopsorhamdia iheringi & Ceih & 98818 & 0.01 & 0.10 & 25.10 & 56.78 & 0.58 & 17.28 & 0.15 & - & - & 0.01 & - & - \\
\hline Characidium gomesi & Chgo & 98815 & 0.00 & 0.47 & 65.67 & 28.46 & 0.63 & 4.39 & 0.35 & - & - & - & - & 0.01 \\
\hline Characidium oiticicai & Choi & 98814 & - & 0.01 & 47.87 & 46.44 & 0.12 & 5.25 & 0.08 & - & - & - & - & 0.22 \\
\hline Corydoras aeneus & Coae & 98828 & 2.67 & - & 9.12 & 14.06 & 3.10 & 56.90 & 9.24 & - & - & 1.39 & - & 3.51 \\
\hline Geophagus brasiliensis & Gebr & 98829 & 0.93 & - & 27.88 & 8.73 & 7.73 & 48.32 & 4.85 & 0.00 & 0.14 & 0.01 & 0.21 & 1.20 \\
\hline Gymnotus carapo & Gyca & 98833 & 0.04 & 0.01 & 13.11 & 39.43 & 10.33 & 34.54 & 1.20 & 0.44 & 0.20 & 0.56 & 0.07 & 0.07 \\
\hline Imparfinis mirini & Immi & 98817 & 0.04 & 0.03 & 19.33 & 53.02 & 3.67 & 23.18 & 0.01 & 0.13 & - & - & 0.24 & 0.35 \\
\hline Trichomycterus brasiliensis & Trbr & 98826 & 0.01 & 0.04 & 12.59 & 62.01 & 3.51 & 16.21 & 3.37 & - & - & 0.68 & 1.53 & 0.05 \\
\hline Trychomytcerus $\mathrm{sp}$. & Trsp & 98824 & - & - & 39.54 & 43.89 & 0.03 & 14.63 & 1.66 & - & 0.06 & 0.20 & - & 0.00 \\
\hline Astyanax altiparanae & Asal & 98805 & 0.14 & 1.98 & 31.29 & 15.99 & 21.52 & 26.25 & 0.35 & 0.05 & - & 1.42 & 0.35 & 0.66 \\
\hline Astyanax paranae & Aspa & 98807 & 0.54 & 0.25 & 10.10 & 26.70 & 36.95 & 24.45 & 0.03 & - & - & 0.32 & - & 0.66 \\
\hline Neoplecostomus paranensis & Nepa & 98821 & 20.14 & - & 27.96 & 2.27 & 4.02 & 20.97 & 24.63 & - & - & - & - & - \\
\hline Hisonotus depressicauda & Hide & 98819 & 5.49 & - & - & - & 3.95 & 25.22 & 65.44 & - & - & - & - & - \\
\hline Hypostomus ancistroides & Hyan & 98820 & 5.42 & - & 0.08 & 0.01 & 6.31 & 20.33 & 67.84 & - & - & 0.00 & - & 0.02 \\
\hline Phalloceros sp. & Phsp & 98831 & 1.41 & 0.01 & 0.79 & 2.90 & 8.41 & 49.92 & 36.45 & 0.05 & - & - & - & 0.05 \\
\hline Poecillia reticulata & Pore & 98832 & 9.71 & - & 2.68 & 9.89 & 1.24 & 40.11 & 36.35 & - & - & - & - & - \\
\hline Pareiorhina sp. & Pasp & 98822 & 15.82 & - & 0.23 & 0.00 & 2.63 & 3.04 & 78.29 & - & - & - & - & 0.00 \\
\hline Hoplias malabaricus & Homa & 98816 & - & - & - & 0.13 & 0.33 & 0.09 & 0.14 & - & 99.32 & - & - & - \\
\hline Rhamdia quelen & Rhqu & 98827 & 0.01 & 0.05 & 10.66 & 23.47 & 1.41 & 24.56 & 0.50 & 23.34 & 6.80 & - & 9.07 & 0.14 \\
\hline Tilapia rendalli & Tire & 98830 & 8.67 & - & 0.22 & 1.12 & 72.29 & 11,93 & 2.37 & - & 2.47 & - & - & 0.93 \\
\hline
\end{tabular}


Table 3. Frequency of occurrence (\%) of food items of 22 fish species of serra do Japi streams (rainy and dry season). Species codes in Table 2. undet. $=$ undetermined.

\begin{tabular}{|c|c|c|c|c|c|c|c|c|c|c|c|c|c|c|c|c|c|c|c|c|c|c|c|}
\hline Species & Asal & Asbo & Aspa & Brstr & Ceih & Chgo & Choi & Coae & Gebr & Gyca & Hide & Homa & Hyan & Immi & i Nepa & Pasp & Phsp & Pore & Rhqu & Tire & Trbr & Trsp & $\begin{array}{r}\text { Total } \\
(\%)\end{array}$ \\
\hline \multicolumn{24}{|l|}{ AQUATIC ORIGIN } \\
\hline Chironomidae & 10.2 & 8.2 & 4.5 & 16.7 & 18.6 & 18.2 & 12.2 & 12.1 & 16.0 & 12.6 & & & 2.8 & 13.6 & 7.8 & 2.9 & 2.4 & 3.3 & 5.0 & & 12.2 & 19.7 & 9.0 \\
\hline Ceratopogonidae & & & & & 1.4 & & & 1.3 & 0.5 & 3.6 & & & & 2.9 & & & & & 2.5 & & & 0.7 & 0.6 \\
\hline Culicidae & & & & & & 0.6 & 2.0 & & & & & & & & & & & & 2.5 & & & & 0.2 \\
\hline Diptera (undet.) & 1.6 & 2.0 & 1.9 & 6.7 & & 1.3 & & 1.3 & & 4.3 & & & & 1.9 & 1.4 & & & 1.3 & 2.5 & & 2.7 & 2.2 & 1.4 \\
\hline Simuliidae & 8.7 & 6.1 & 6.5 & 3.3 & 10.0 & 19.5 & 8.8 & 2.1 & 1.9 & 4.3 & & & & 2.9 & 9.2 & 1.2 & 1.2 & 3.3 & 2.5 & 2.1 & 5.4 & 5.1 & 4.7 \\
\hline Ephemeroptera & 1.6 & & 0.6 & 3.3 & 2.9 & 6.5 & 9.5 & & & & & & & & 2.8 & & 0.6 & & & & 1.4 & 2.2 & 1.4 \\
\hline Plecoptera & & & & & & 3.2 & 1.4 & & & & & & & & 0.7 & & & & & & & 0.7 & 0.3 \\
\hline Coleoptera & 1.6 & & 0.6 & & & & 0.7 & & & & & & & & & & & & 2.5 & & & & 0.2 \\
\hline Trichoptera & 5.5 & & 5.2 & 3.3 & 14.3 & 6.5 & 15.5 & 0.8 & 6.3 & 7.9 & & & & 10.7 & 2.1 & & 1.2 & & 2.5 & & 4.1 & 10.2 & 4.4 \\
\hline Odonata & & 2.0 & 0.6 & & & 0.6 & 1.4 & & 1.0 & 2.4 & & & & 1.0 & & & & & 2.5 & & & & 0.5 \\
\hline Cladocera & & & & & & & & 0.4 & 0.5 & & & & & & & 0.6 & 0.6 & & & & & & 0.1 \\
\hline Copepoda & & & & & & & & 1.7 & 1.5 & & & & 1.1 & & & & & & & & & 0.7 & 0.2 \\
\hline Ostracoda & 0.8 & & & & & & & 5.0 & 3.4 & & & & & 2.9 & & & 0.6 & & & & 1.4 & 0.7 & 0.7 \\
\hline Aeglidae & & & & & & & & & & 0.8 & & & & 1.0 & & & & & 7.5 & & & & 0.4 \\
\hline Isopoda & 1.6 & & & & & & & & 0.5 & 1.6 & & & & 1.0 & & & 1.2 & & & & & & 0.3 \\
\hline Decapoda & & & & & & & & & & & & & & 1.0 & & & & & 5.0 & & & & 0.3 \\
\hline Nematoda & 5.5 & 4.1 & 3.2 & 3.3 & 2.9 & & & 3.8 & & 2.8 & & & 0.6 & & & & & & & & 4.1 & 3.6 & 1.5 \\
\hline Oligochaeta & 1.6 & & & & & & & & 1.0 & 0.4 & & & & 1.0 & & & & & 5.0 & & 2.7 & & 0.5 \\
\hline Acarina & & & & & & 1.3 & 3.4 & 0.8 & 1.0 & & & & & & & & & & & & & & 0.3 \\
\hline Tecameba & & & & & & & & 4.2 & 1.0 & 2.8 & & & 0.6 & & & & & & & & 2.7 & & 0.5 \\
\hline Osteichthyes & & 2.0 & & & & & & & & 0.8 & & 62.5 & & & & & & & 7.5 & 4.2 & & 0.7 & 3.5 \\
\hline Scale & 0.8 & & 1.9 & & & & 0.7 & & 0.5 & 1.2 & & & & & & & & & & 4.2 & & & 0.4 \\
\hline Bacillariophyceae & 3.9 & 2.0 & 2.6 & 3.3 & & & & 12.1 & 7.3 & 1.2 & 20.0 & & 18.8 & 1.9 & 17.0 & 21.8 & 11.4 & 16.7 & & 18.8 & 1.4 & & 7.2 \\
\hline Chlorophyceae & 3.1 & 4.1 & 3.2 & 3.3 & 1.4 & 0.6 & & 7.1 & 5.8 & 2.0 & 6.7 & & 11.6 & 1.9 & 12.1 & 8.2 & 7.2 & 10.0 & & 12.5 & & & 4.6 \\
\hline Cyanophyceae & & & 1.9 & 6.7 & & & & 2.9 & 0.5 & 0.4 & 13.3 & & 9.4 & & 4.3 & 15.3 & 3.6 & 2.0 & & 12.5 & & & 3.3 \\
\hline Bivalvia & & & & & & & & & & & & & & & & & & & 2.5 & & & & 0.1 \\
\hline \multicolumn{24}{|c|}{ TERRESTRIAL ORIGIN } \\
\hline Coleoptera (adult) & & & & & 1.4 & 0.6 & 0.7 & & & 0.4 & & & & 1.0 & & & & & 2.6 & & & & 0.3 \\
\hline Diptera & 0.8 & & & & & 0.6 & & & & & & & & & & & & & & & & & 0.1 \\
\hline Hymenoptera & 4.7 & & 1.3 & & & & & & & & & & & & & & 0.6 & & & & & & 0.3 \\
\hline $\begin{array}{l}\text { Lepidoptera } \\
\text { (lmature) }\end{array}$ & & & & & & & & & & & & & & & & & & & & & & & 0.0 \\
\hline Arachnidae & 0.8 & & 0.6 & & & & & & & & & & & 1.0 & & & & & & & & & 0.1 \\
\hline \multicolumn{24}{|c|}{ INDETERMINATE } \\
\hline Insects Fragments & 13.4 & 24.5 & 19.5 & 20.0 & 21.4 & 20.9 & 20.8 & 13.4 & 10.2 & 15.4 & & 12.5 & 1.1 & 22.3 & 5.0 & 1.2 & 9.6 & 11.3 & 17.5 & 6.3 & 25.7 & 24.1 & 14.3 \\
\hline Vegetal Matter & 13.4 & 12.2 & 18.8 & 10.0 & 4.3 & 5.2 & 2.7 & 7.9 & 11.2 & 13.0 & 20.0 & 12.5 & 16.6 & 8.7 & 12.1 & 14.1 & 14.4 & 8.0 & 7.5 & 18.8 & 4.1 & 0.7 & 10.7 \\
\hline Seeds & 3.1 & & 1.9 & 3.3 & & & & 0.4 & 0.5 & 0.4 & & & & 1.0 & & & & & & & & & 0.5 \\
\hline Organic $m$ & 14.2 & 24.5 & 22.1 & 13.3 & 18.6 & 11.0 & 13.5 & 10.0 & 18.9 & 15.4 & 20.0 & 12.5 & 17.7 & 21.4 & 12.8 & 11.8 & 22.8 & 22.0 & 20.0 & 12.5 & 18.9 & 19.0 & 16.9 \\
\hline Detritus & 3.1 & 6.1 & 1.3 & 3.3 & 2.9 & 3.2 & 2.0 & 12.1 & 9.2 & 5.9 & 20.0 & 12.5 & 19.3 & 1.0 & 12.1 & 22.9 & 22.8 & 22.0 & 5.0 & 8.3 & 13.5 & 9.5 & 9.9 \\
\hline Eggs & & 2.0 & 1.3 & & & & 0.7 & 0.4 & 1.0 & & & & & & & & 0.6 & & & & & & 0.3 \\
\hline Stomaches analysed & 22 & 12 & 40 & 6 & 17 & 39 & 40 & 40 & 40 & 40 & 6 & 6 & 39 & 25 & 25 & 40 & 40 & 32 & 16 & 10 & 22 & 22 & 589 \\
\hline
\end{tabular}

often observed in streams of tropical regions (Uieda et al., 1997; Castro \& Casatti, 1997; Luiz et al., 1998; Buck, 2000; Casatti et al., 2001). Aquatic invertebrates, mainly insects in various stages of development, are also common in the diet of species of freshwater fish (Russo et al., 2002). The insectivorous species of Serra do Japi streams used large proportions of aquatic insects, including groups which may be indicative of the good state of preservation of some sampling sites (trichoptera and ephemeroptera nymphae), given the basic requirements needed for their occurrence in highly oxygenated waters (McCfferty, 1981).

Observed diet differences between the group of insectivores composed by C. gomesi, C. oiticicai and Trichomycterus sp. which fed predominantly on benthic insect larvae and the group composed of I. mirini, C. iheringi and T. brasiliensis may be probably related to the use of different micro-habitats, periods of activity and feeding tactics, commonly observed in tropical regions (Moyle \& Senanayake, 1984; Sabino \& Castro, 1990; Esteves \& Galetti Jr., 1995). Some morphological characteristics of $T$. brasiliensis such as the presence of a cephalic intestine, adapted to a diversified diet and the presence of gill rakers as well, which may retain larger prey and allow the species to ingest animal food including fish (Ribeiro \& Menin, 1996), may also explain the diet differences in relation to Trichomycterus sp.

Among the Loricariidae, three species were considered detritivores, occurring in habitats with a predominance of gravel and sand ( $H$. ancistroides and $H$. depressicauda) and boulders and rapids (Pareiorhina sp.). The presence of algal tufts in the diet of this species suggests the use of grazing tactics similar to other armored catfishes such as Kronichthys heylandii, Harttia kronei and Schizolecis guentheri which occupy the rocky and sandy bottom of Atlantic Forest streams and graze basically on algae (Buck \& Sazima, 1995). As ob- 

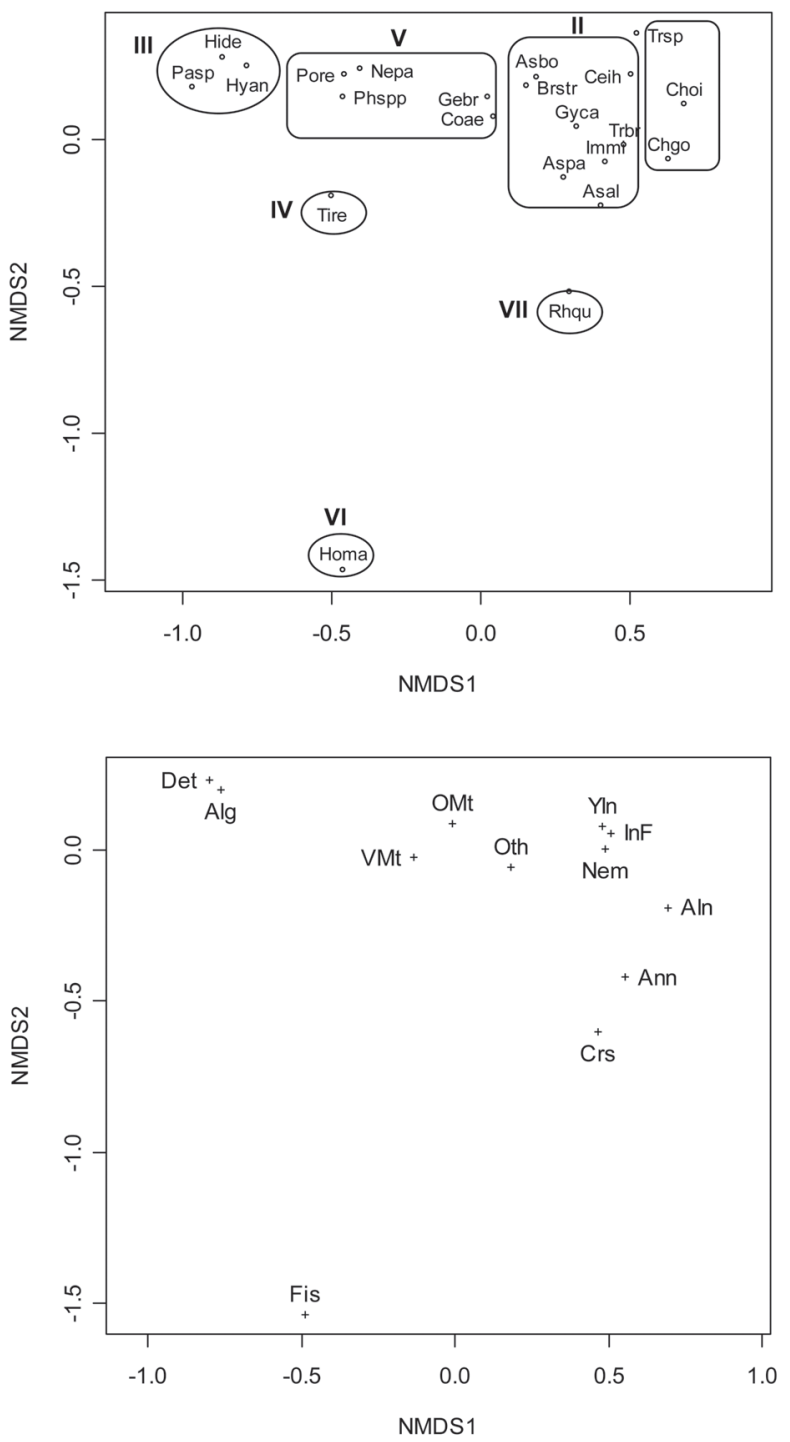

Fig. 2 a-b. Scores of NMDS for the fish species (a) and food items (b) along the axes 1 and 2. Circles and rectangles (a) indicate trophic groups formed by the similarity array. Benthic insectivores (I), insectivores (II), detritivores (III), herbivores (IV), omnivores (V), piscivores (VI), omnivore-carnivores (VII). (b) $\mathrm{Alg}=$ algae; Det $=$ detritus; $\mathrm{OMt}=$ organic matter; $\mathrm{VMt}=$ vegetal matter; Oth $=$ others, YIn = young insects; Fis=fish; AIn $=$ adult insects; $\mathrm{InF}=$ insect fragments, $\mathrm{Nem}=$ nematodes; Ann $=$ Annelidae, $\mathrm{Crs}=$ Crustacea . Codes of species are shown in Table 2.

served by Garavello \& Santana (1998) for streams of the Paraiba do Sul and Tietê basins, Pareiorhina sp. seems to be associated with clear water environments, with sediments composed of sand and large boulders, feeding on algae of the periphyton.

Analysis of the origin of the food items revealed that aquatic-origin resources, especially immature insects and algae were the most important food resources for the fish assemblage, similar to findings of other studies (Sabino \& Castro, 1990; Uieda et al., 1997; Casatti, 2002; Deus \& Petrere

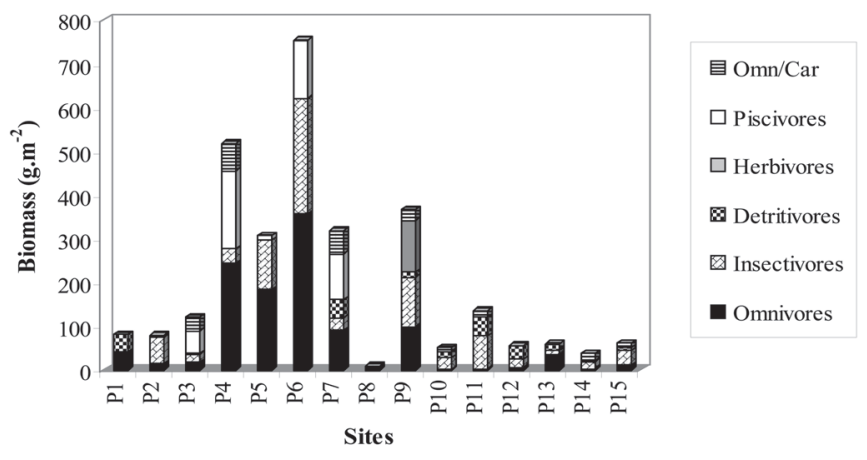

Fig. 3. Biomass $\left(\mathrm{g} \cdot \mathrm{m}^{-2}\right)$ of the different trophic groups of fish at each collecting site in Serra do Japi (SP) streams.

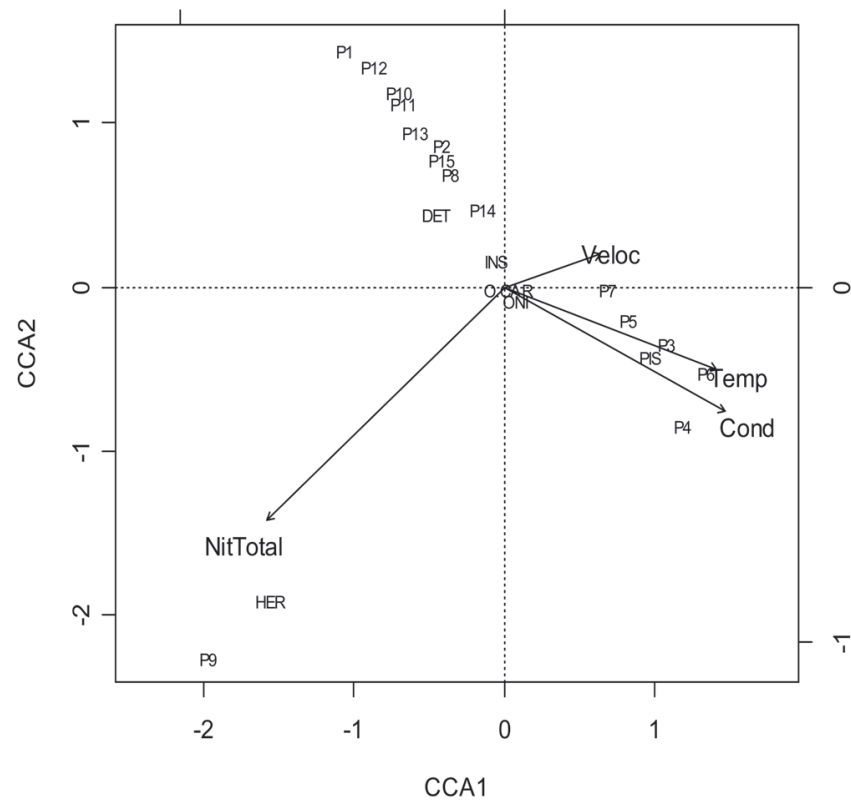

Fig. 4. Canonical Correspondence Analysis (CCA) showing the relationship between the biomass of insectivores (INS), omnivores (ONI), herbivores (HER), detritivores (DET), piscivores (PIS), omnivores-carnivores (O.CAR) and selected environmental variables. Temp $=$ temperature; Veloc $=$ Water Velocity; T.Nit $=$ total nitrogen, Cond $=$ Conductivity.

Jr., 2003) in southeastern brazilian streams. In other tropical rainforest streams, however, the importance of allochthonous food items has been highlighted, as these represent an important input of organic matter into the system (Henry et al., 1994), being considered the basis of the food chain in some stream ecosystems (Gregory et al., 1991). These apparently contradictory results can be explained by the relative importance of food of terrestrial and aquatic origin, the composition of the fish assemblage, the specific adaptations for feeding on aquatic organisms, as well as by the environmental 
Table 4. Results of Canonical Correspondence Analysis (CCA) on fish guild biomass and selected environmental variable .Variable/ Axis = Biplot scores for constraining variables.

\begin{tabular}{lcccc}
\hline \multicolumn{1}{c}{ Variable/Axis } & 1 & 2 & 3 & 4 \\
\hline Temperature & 0.65 & -0.23 & 0.58 & 0.23 \\
Total Nitrogen & -0.73 & -0.65 & 0.07 & 0.19 \\
Water Velocity & 0.30 & 0.09 & 0.03 & 0.95 \\
Conductivity & 0.67 & -0.35 & -0.47 & 0.44 \\
\hline \multicolumn{1}{c}{ Axis } & & & & \\
\hline Eigenvalues & 0.21 & 0.16 & 0.02 & 0.01 \\
Percentual cumulative variation & 0.35 & 0.62 & 0.67 & 0.68 \\
Species/Variable correlation & 0.95 & 0.93 & 0.53 & 0.39 \\
\hline
\end{tabular}

conditions of the streams studied (Melo et al., 2004; Dias et $a l ., 2005)$. In our study, many of the species seemed to be morphologically adapted to bottom feeding. This behavior, associated with a more intense growth of algae in several sites were forest canopy was less dense (allowing sunlight to reach the water), could explain the predominance of authochthonous items in the fishes diet.

The analysis of the trophic structure of the fish assemblage of the Serra do Japi indicated the existence of seven trophic groups, similar to those described by Esteves \& Lobón-Cerviá (2001) in Atlantic Forest streams in southeastern Brazil and higher than in other stream studies (Sabino \& Castro,1990; Casatti, 2002). In the Paraná River basin, the number of trophic guilds varied from 7 to 10 (Hahn et al., 1997a; Luz-Agostinho, 2006). The comparison of the number of trophic groups within communities is often hampered by several factors, and must consider the diversity based on resources available, the number and morphological diversity of species present, the availability of prey in the environment (Pusey et al., 1995), and the use of different methods to separate the guilds as well, which suggests the need to standardize these methods in order to make comparisons possible.

Trophic organization seems to be related to habitat variables, as shown by Chipps et al. (1994), Rabeni \& Smale (1995) and Zambrano et al. (2006). Generally, stream flow has been a major influence on fish communities like many other physical variables as substratum, depth, presence of debris, habitat heterogeneity and physical-chemical factors such as temperature and oxygen (Schlosser, 1990). In Serra do Japi streams, according to the canonical correspondence analysis (CCA), the most important variables in the distribution of the different trophic groups were total nitrogen, temperature, conductivity and temperature. Although a direct correlation between selected variables and the presence of certain trophic groups cannot be directly established, the presence of the herbivore group ( $T$. rendalli) was probably related to the transportation process from local fish ponds rather than to the high total nitrogen values (P9), caused by the input of animal excrements.

Several studies show that some fish species are particularly associated with good physical habitat conditions (Casatti et al., 2006b), as was observed for the detritivore group formed by H.ancistroides, Pareiorhina sp. and
H.depressicauda, which showed a preference for preserved conditions. Power (1990) and Antoniassi et al. (1998) observed the environmental preferences of Hypostomus species for clean and running waters of brazilian rivers, while Garavello \& Santana (1998) observed similar requirements for Pareiorhina $\mathrm{sp}$. These species are probably negatively affected by alterations such as removal of the vegetation or siltation due to the embeddedness of the rocky substrate.

On the other hand our study showed that a higher piscivore biomass was associated to the more impacted sites (P4, P5, P6, P7), which can be attributed to the presence of large piscivores such as H.malabaricus. Since a higher biomass of other trophic groups as insectivores and omnivores was recorded at these sites and considering that other habitat features such as the presence of hiding places including trunks and roots was similar to the other areas, one can suggest that piscivores occurred in the most impacted sites because of greater food availability. The combination of higher temperatures, conductivity and total phosphorus at these sites (Rolla, 2008) may have contributed to an increase in productivity, as also suggested by Treviño et al. (1969) and Paul \& Meyer (2001) which have shown that nutrient loads can stimulate fish production. In North American streams Scott et al. (1986) found that fish grew more rapidly and to larger sizes in urban sites, increasing fish production when compared to forested sites, presumably as a result of warmer temperatures and greater invertebrate biomass in the urban stream.

Considering that a loss of habitat quality results in a change in trophic structure, with dominance of generalist species (Casatti et al., 2006a), the diversity of feeding groups found in this study seems to indicate that the fish fauna in the Serra do Japi streams is maintained due to the physical integrity of most of the sites studied. However, fish assemblage in the most disturbed sites showed a different structure, suggesting that loss of stream integrity with the spread of low-density levels of urbanization may have occurred. As changes in fish assemblages do not occur immediately following impacts such as urbanization, but may take many years with gradual replacement of species (Fitzgerald et al., 1998), our results reinforce the importance of promoting the conservation of riparian vegetation and the control of sewage in the region, in order to maintain the integrity of stream habitats and its fish fauna.

\section{Acknowledgments}

We are grateful to Osvaldo T. Oyakawa of MZUSP for identification of fish species, IBAMA for the sampling license (Proc. 02027.002726/2006-16) and Instituto de Pesca (APTA/ SAA) for the infrastructure provided for this work. We also thank Claúdia Eiko Yoshida (UNESP) and Luciana C.B. de Menezes (Instituto de Pesca-SP) for their help in the identification of insects, Eduardo Pontes for the help in the location of the sampling sites, Ginaldo A.C. Campanha (IG) for aid in map locations and Mirna Ferracini for the construction of maps. Natália Furlan and Sergio Luis da Silva 
kindly helped in the field work. Finally, Dr. A. Leyva assisted with English editing of the manuscript.

\section{Literature Cited}

Ab'Saber, A. N. 1992. A Serra do Japi, sua origem geomorfológica e a teoria dos refúgios. In: Morellato, L. P. C. (ed). História Natural da Serra do Japi: ecologia e preservação de uma área florestal no sudeste do Brasil. Campinas, Unicamp/FAPESP, 321p.

Angermeier, P. L. \& J. R. Karr. 1983. Fish communities along environmental gradients in a system of tropical streams. Environmental Biology of Fishes 9:117-135.

Antoniassi, L. E., A. A. Agostinho, L. C. Gomes \& N. S. Hahn. 1998. Ecologia trófica de peixes em dois riachos da bacia do Rio Paraná. Revista Brasileira de Biologia, 58(2): 273-285.

Apha, 1989. Standard methods for the examination of water and freshwater. Washington: American Public Health Association. 1286p.

Barreto, A. P. \& J. M. R. Aranha. 2006. Alimentação de quatro espécies de Characiformes de um riacho da Floresta Atlântica, Guaraqueçaba, Paraná, Brasil. Revista Brasileira de Zoologia, 23(3): 779-788.

Britski, H. A. 1972. Peixes do Estado de São Paulo - Sistemática. In: Comissão Interestadual da Bacia Paraná-Uruguai. Poluição e Piscicultura. São Paulo.

Britski, H. A., S. Sato. \& A. B. S. Rosa. 1986. Manual de identificação de peixes da região de Três Marias (com chaves de identificação para peixes da Bacia do Rio São Francisco). $2^{\mathrm{a}}$ ed. Brasília: CODEVASF, $115 \mathrm{p}$.

Buck, S. \& I. Sazima. 1995. An assemblage of mailed catfishes (Loricariidae) in southeastern Brazil: distribution, activity and feeding. Ichthyological Exploration of Freshwaters 6:325-332.

Buck, S. 1994. História natural de uma comunidade de cascudos (Loricariidae) na Mata Atlântica: habitat, atividade e alimentação. MsC Dissertation, Universidade do Estado de São Paulo, São Paulo. 64p.

Buck, S. 2000. Alimentação e reprodução em peixes Siluriformes (Teleostei) em um rio de Mata Atlântica, Alto Ribeira, São Paulo. PhD. Dissertation, Universidade de São Paulo, São Paulo. 172p.

Casatti, L., F. Langeani \& C. P. Ferreira. 2006a. Effects of physical habitat degradation on the stream fish assemblage structure in a pasture region. Environmental Management, 38: 974-982.

Casatti, L., F. Langeani, A. M. Silva \& R. M. C. Castro. 2006b. Stream fish, water and habitat qaulity in a pasture dominated basin, southeastern Brazil. Brazilian Journal of Biology, 66(2B): 681-696.

Casatti. L. 2002. Alimentação dos peixes de um riacho do Parque Estadual Morro do Diabo, Bacia do Alto rio Paraná, SP. Biota Neotropica, 2(2): 1-14.

Casatti. L., F. Langeani \& R. M. C. Castro. 2001. Peixes de riacho do Parque Estadual do Morro do Diabo, bacia do Alto rio Paraná, SP. Biota Neotropica, 1(1/2):1-15.

Castro, R. M. C. \& L. Casatti. 1997. The fish fauna of a small forest stream of the upper Paraná river basin, southeastern Brazil. Ichthyological Explorations of Freshwaters, 7(4): 337-352.

Castro, R. M. C. \& N. A. Menezes. 1998. Estudo diagnóstico da diversidade de peixes do estado de São Paulo. In: Joly, C. A. \& C. E. M. Bicudo. Biodiversidade do Estado de São Paulo, Brasil; síntese do conhecimento ao final do século XX; 6: Vertebrados. FAPESP, São Paulo, 71p.

CETESB. 1978. Normatização Técnica. Companhia de Tecnologia e Saneamento Ambiental de São Paulo. São Paulo: CETESB.

Chipps, S. R., W. B. Perry \& S. A. Perry. 1994. Fish assemblage of the Central Appalachian Mountains: an examination of trophic abundance in nine West Virginia streams. Environmental Biology of Fishes, 40: 91-98.

Clarke, K. R. \& R. M. Warwick. 1994. Change in marine communities: an approach to statistical analysis and interpretation. Plymouth Marine Laboratory, Plymouth, UK, $144 p p$.

Deus, C. P. \& M. Petrere-Jr. 2003. Seasonal diet of seven fish species in an Atlantic rainforest stream in southeastern Brazil. Brazilian Journal of Biology, 63(4) 579-588.

Dias, A. C. M. I., C. W. C. Branco \& V. G. Lopes. 2005. Estudos da dieta natural de peixes no reservatório de Ribeirão das Lajes, Rio de Janeiro, Brasil. Acta Scientiarum, 27(4): 355-364.

Esteves, K. E. \& J. Lobón-Cerviá. 2001. Composition and trophic structure of a fish community of a clear water Atlantic rainforest stream in southeastern Brazil. Environmental Biology of Fishes 62: 429-440.

Esteves, K. E. \& J. M. R. Aranha. 1999. Ecologia trófica de peixes de riachos. Pp. 157-182. In: Caramaschi, E. P., R. Mazzoni, \& P. R. Peres-Neto (eds). Ecologia de peixes de riachos. Série Oecologia Brasiliensis. Vol Vl. Rio de Janeiro, PPGE-UFRJ, 206p.

Esteves, K. E. 1996. Feeding ecology of three Astyanax species (Characidae, Tetragonopterinae) from a floodplain lake of MogiGuaçú River, Paraná River Basin, Brazil. Environmental Biology of Fishes, 46: 83-101.

Esteves, K. E. \& P. M. Galetti Jr. 1995. Food partitioning among some characids of a small Brazilian foodplain lake from the Paraná River basin. Environmental Biology of Fishes, 42: 375-389.

Esteves, K. E., A.V. Pinto-Lobo \& M. D. R. Faria. 2008. Trophic structure of a fish community along environmental gradients of a subtropical river (Paraitinga River, Upper Tietê River Basin, Brazil). Hydrobiologia, 598: 373-387.

FEEMA, 1981. Métodos de análises físico-química da água. Rio de Janeiro: Fundação Estadual de Engenharia do Meio Ambiente.

Fitzgerald, D. G., E. Kott, R. P. Lanno \& D. G. Dixon. 1998. A quarter century of change in the fish assemblages of three small streams modified by anthropogenic activities. Journal of Aquatic Ecosystem Stress and Recovery, 6: 111-127.

Garavello, J. C. \& I. C. Santana. 1998. Functional morphology, ecology and geographic distribution of the neotropical catfish genus Pareiorhina Gosline, 1947, from southeastern Brazilian rivers (Pisces, Loricariidae, Hypostominae). Verhandlungnen der Internationalen Vereinigung für Limnologie, 26: 2240-2243.

Gelwick, F. P. \& W. J. Matthews. 1996. Trophic relations of streams fishes. Pp. 475-492. In: Hauer, F. R. \& G. A. Lamberti (Eds). Methods in Stream Ecology. San Diego: Academic Press. 674p.

Gorman, O. T. \& Karr, J. R. 1978. Habitat structure and stream fish communities. Ecology, 59: 507-515.

Gregory, S. V., F. J. Swanson, W. A. McKee \& K. W. Cummings. 1991. An ecosystem perspective of riparian zones: focus on links between land and water. Bioscience, 41: 540-551.

Hahn, N. S., R. Fugi, V. L. L. Almeida, M. R. Russo \& V. E. Loureiro. 1997a. Dieta e atividade alimentar de peixes do reservatório de Segredo. Pp. 141-162. In: Agostinho, A. A. \& C.G. Gomes. Reservatório de Segredo: bases ecológicas para o manejo. Maringá, Eduem, 387p.

Hahn, N. S., V. L. L. Almeida \& K. D. G. Luz. 1997b. Alimentação e ciclo alimentar diário de Hoplosternum littorale (Hancock) (Siluriformes, Callichthyidae) nas lagoas Guaraná e Patos da Planície do Alto Paraná, Brasil. Revista Brasileira de Zoologia, 14(1):57-64.

Hawksworth, D. L. 1995. The resource base for biodiversity assessments. Pp 549-605. In: V. H. Heywood \& R. T. Watson, 
(eds). Global biodiversity assessment. Cambridge University Press, Cambridge, United Kingdom.

Henry, R., V. S. Uieda, A. A. O. Afonso \& R. M. Kikuchi. 1994. Input of allochthonous matter and structure of fauna in a brazilian headstream. Verhandlungnen der Internationalen Vereinigung für Limnologie, 25(3): 1866-1870.

Hynes, H. B. N. 1950. The food of freshwater sticklebacks (Gasterosteus aculeatus and Pygosteus pungitius) with a review of methods used in studies of the food of fishes. Journal of Animal Ecology, 19:36-58.

Instituto Serra do Japi. 1998. O Patrimônio Natural Serra do JapiRiscos e Ações para Preservação. Literarte. 86p.

Jeppesen E., J. P. Jensen, M. Søndergaard, T. Lauridsen \& F. Landkildehus. 2000. Trophic structure, species richness and biodiversity in Danish lakes: changes along a phosphorus gradient. Freshwater Biology, 45:201-218.

Joly, C. A. 1992. Preservação da Serra do Japi. Pp 310-321. In: Morellato, L. P. C. (ed). História Natural da Serra do Japi ecologia e preservação de uma área florestal do sudeste do Brasil. Campinas, Unicamp/FAPESP, 321p.

Karr, J. R. 1981. Assessment of biotic integrity using fish communities. Fisheries 6(6): 21-27.

Kawakami, E. \& G. Vazzoler. 1980. Método gráfico e estimativa de índice alimentar aplicado no estudo de alimentação de peixes. Boletim do Instituto Oceanográfico 29:205-207.

Luiz, E. A., A. A. Agostinho, L. C. Gomes \& N. S. Hanh. 1998. Ecologia trófica de peixes em dois riachos da bacia do Rio Paraná. Revista Brasileira de Biologia, 58(2): 273-285.

Luz-Agostinho, K. D. G., L. M. Bini, R. Fugi, A. A. Agostinho \& F.Júlio Jr. 2006. Food spectrum and trophic structure of the ichtyofauna of Corumbá reservoir, Paraná river Basin, Brazil. Neotropical Ichthyology, 4(1): 61-68.

Marques, V.S. \& M. S. F. Argento. 1998. O uso de flutuadores para avaliação da vazão de canais fluviais. Geociência, 7: 173-186.

Mazzoni, R., N.Fenerich-Verani \& E. P. Caramaschi. 2000. Electrofishing as a sampling technique for coastal stream fish population and communities in the Southeast of Brazil. Revista Brasileira de Biologia, 60: 205-216.

McCafferty, W. P. 1981. Aquatic entomology: the fishermen's and ecologist's illustrated guide to insects and theirs relatives. Boston: Jones an Barlett, 861p.

Melo, C. E., F. A. Machado \& V. Pinto-Silva. 2004. Feeding habits of fish from a stream in the savanna of Central Brazil, Araguaia Basin. Neotropical Ichthyology, 2(1): 37-44.

Menezes, N. A. 1994. Importância da conservação da ictiofauna dos ecossistemas aquáticos brasileiros. Pp. 7-13. In: Seminário sobre fauna aquática e o setor elétrico basileiro. Caderno 3. Conservação. Comitê Coordenador das Atividades de Meio Ambiente do Setor Elétrico COMASE. Rio de Janeiro: Eletrobraz.

Menezes, N. A., R. M. C. Castro, S. Weitzman \& M. J. Weitzman. 1990. Pp. 290-295. Peixes de riacho da Floresta Costeira Atlântica Brasileira: um conjunto pouco conhecido e ameaçado de vertebrados. In: Simpósio de Ecossistemas da Costa Sul e Sudeste brasileira: estrutura, função e manejo. Águas de Lindóia, São Paulo: Academia de Ciências do Estado de São Paulo.

Morellato, L. P. C. 1992. Introdução. Pp. 8-11. In: Morellato, L. P. C (ed). História Natural da Serra do Japi - ecologia e preservação de uma área florestal do sudeste do Brasil. Campinas, Unicamp/FAPESP, 321p.

Motta, R. L. \& V. S. Uieda. 2005. Food web structure in a tropical stream ecosystem. Austral Ecology, 30:58-73.

Moyle, P. B. \& F. R. Senanayake. 1984. Resource partitioning among the fishes of rainforest streams in Sri Lanka. Journal of Zoology, 202: 195-223.

Myers, N., R. A. Mittermeier, C. G. Mittermeier, G. A. B. Fonseca \& J. Kent. 2000. Biodiversity hotspots for conservation priorities. Nature, 403: 853-858.

Oksanen, J., R. Kindt, P. Legendre, B. O’Hara \& M. H. H. Stevens. 2007. Vegan: Community Ecology Package. R package version 1.8-8. http://cran.r-project.org./; http://r-forge.r-project.org/ projects/vegan/.

Paul, M. J. \& J. L. Meyer. 2001. Streams in the urban landscape. Annual Review of Ecology and Systematics, 32: 333-365.

Power, M. E. 1990. Resource enhancement by indirect effects of grazers: armored catfish, algae and sediment. Ecology, 7: 897-904.

Pusey, B. J., M. G. Read \& A. H. Arthington. 1995. The feeding ecology of freshwater fishes in two rivers of the Australian wet tropics. Environmental Biology of Fishes, 43: 85-103.

R Development Core Team. 2007. R: A language and environment for statistical computing. R Foundation for Statistical Computing. Vienna, Áustria. ISBN 3-900051-07-0, URL http:/ /www.R-project.org.

Rabeni, C. F. \& M. A. Smale. 1995. Effects of siltation on stream fishes and the potential mitigating role of the buffering riparian zone. Hydrobiologia, 303: 211-219.

Ribeiro, C. A. de O. \& E. Menin. 1996. Anatomia da cavidade bucofaringeana de Trichomycterus brasiliensis (Reinhart) e suas relações com os hábitos alimentares (Siluroidei, Trichomycteridae). Acta Biologica Paranaense, 25: 159-171.

Rolla, A. P. P. R. 2008. A ictiofauna da Serra do Japi: bases para conservação. MsC Thesis, Instituto de Pesca, São Paulo. 117p.

Russo, M. R., A. Ferreira \& R. M. Dias. 2002. Disponibilidade de invertebrados aquáticos para peixes bentófagos de dois riachos da bacia do rio Iguaçu, Estado do Paraná, Brasil. Acta Scientiarum, 24(2): 411-417.

Sabino, J. \& R. M. C. Castro. 1990. Alimentação, período de atividade e distribuição espacial dos peixes de um riacho de floresta Atlântica (Sudeste do Brasil). Revista Brasileira de Biologia, 50: 23-36.

Schiemer, F. \& M. Zalewski. 1992. The importance of riparian ecotones for diversity and productivity of riverine fish communities. Netherland Journal of Zoology, 42: 323-335.

Schlosser, I. J. 1990. Environmental variation, life history attributes, and community structure in stream fishes: implications for environmental management and assessment. Environmental Management, 14(5): 621-628.

Scott, J. B., C. R. Steward \& Q. J. Stober. 1986. Effects of urban development on fish population dynamics in Kelsey Creek, Washington. Transactions of the American Fisheries Society, 115: 555-567.

Strickland, J. D. H. \& T. R. Parsons. 1968. A practical handbook of seawater analysis. Fisheries Research Board of Canada Bulletin, 167: $311 \mathrm{p}$.

Tabarelli Pinto, L. P., J. M. C. Silva, M. Hirota \& L. Bedê. 2005. Challenges and Opportunities for Biodiversity Conservation in Brazilian Atlantic Forest. Conservation Biology, 19(3): 695-700.

Treviño, H., J. Torres, P. Choquehuanca, D. A. Levy \& T. G. Northcote. 1969. Effects of eutrophication on fish. Pp 115128. In: Eutrophication: causes, consequences and correctives. Washington, National Academy of Sciences, 661p.

Uieda, V. S. \& M. G. Barreto. 1999. Composição da Ictiofauna de quatro trechos de diferentes ordens do Rio Capivara, Bacia do Tietê, Botucatu, São Paulo. Revista Brasileira de Zoociências 1(1):55-67.

Uieda, V. S. \& R. L. Motta. 2007. Trophic organization and food web structure of southeastern Brazilian streams: a review. Acta 
Limnologica Brasiliensia, 19(1): 15-30.

Uieda, V. S. 1995. Comunidades de peixes de um riacho litorâneo: composição, habitat e hábitos. PhD Dissertation, Universidade de Campinas, Campinas, 200p.

Uieda, V. S., P. Buzzato \& R. Kikuchi. 1997. Partilha de recursos alimentares em peixes em um riacho de serra do Sudeste do Brasil. Anais da Academia Brasileira de Ciências, 69: 243-252.

Vilella, F. S., F. G. Becker \& S. M. Hartz. 2002. Diet of Astyanax species (Teleostei, Characidae) in an Atlantic forest river in southern Brazil. Brazilian Archives of Biology and Technology, 45(2): 223-232.

Zambrano, L., M. R. Perrow, C. D. Sayer, M. L. Tomlinsom \& T. A. Davidson. 2006. Relationships between fish feeding guild and trophic structure in English lowland shallow lakes subject to anthropogenic influence: implications for lakes restoration. Aquatic Ecology, 40 (3): 391-405.

Zippin, C. 1958. The removal method of population estimation. Journal of Wildlife Management, 22:82-90.

Accepted October, 2008

Published March 31, 2009 